
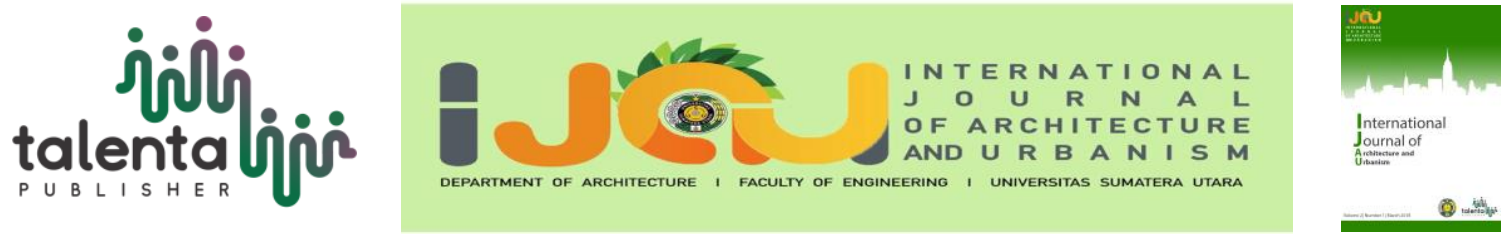

\title{
Huta Tomok Tourism Pier as Samosir Tourism Gate
}

\author{
Nurlisa Ginting ${ }^{1 *}$, Yuda Juliandi ${ }^{1}$ \\ ${ }^{1}$ Department of Architecture, Universitas Sumatera Utara, Medan, Indonesia
}

\begin{abstract}
Samosir is one of the famous tourist attraction for the beautiful view of nature of Lake Toba and some traditional cultural sites. Samosir began to start independent and has they have managing system for every area, and one of them is a tourist attraction. This area has the infrastructure that should be available very well, the most important thing in tourist attraction context in Samosir Island is the water crossing terminal because water transportation is the main part of tourist attractions life in Samosir Island. Tomok Village's dock is one of the main doors that very busy with so many visits from the passenger. To provide a decent service, this dock is still far from expectations. Can be seen from the limit of the passengers this dock can afford, with the increasing intensity of passengers. However, this region needs to redevelopment using every single available potential. In the end, the dockyard should be attractive and give a great experience of Batak Toba culture. The designer will create the cultural experience through the display of the buildings. The designer hopes to facilitate passengers to cross the lake to Samosir island using Tomok village's dockyard.
\end{abstract}

Keyword: dockyard, facility, public space, culture

\section{Introduction}

Tourism is one of the fastest global industry and the major contributor to the gross domestic product of many countries. The growth of tourism is the result of globalization process which is visible in various activities and from [2]. Pangururan is the capital of Samosir in North Sumatra. This region is one of the tourist attraction that already has its fame on local tourist or even international because of its beautiful nature of Lake Toba and some Batak traditional cultural sites. Since the divisions of Toba Samosir in 2003, this region began their independencies and had their area managing system in every sector and tourist is attraction one of them. Proper management of tourism development becomes one of the industries that will create prosperity through the development of transportation because the waters of Lake Toba functioned as water transportation infrastructure that connects between the District in Lake Toba one of them through Tomok Village pier.

*Corresponding author at: Department of Architecture, Faculty of Engineering, Universitas Sumatera Utara,

Jalan Perpustakaan Gedung J07, Medan 20155, Indonesia

E-mail address: nurlisa.ginting@gmail.com 
Tomok Village Dockyard as one of the main entrance that very busy with their many visitors. To give proper service, Tomok Village Dockyard is still far from expectations. Can be seen from the limit of the passengers this dock can afford, with the increasing intensity of passengers. Less optimal accessibility in passengers embarkation and debarkation time made the problem much worst, dock's material made from the pile of dirt and stones that influence passengers security. Lacks facilities development such as the lamp, vegetations, benches, garbages, and shades take parts in aesthetical value and passengers pleasure in docks. After seeing Tomok Village Dockyard's conditions, Samosir has their important role to connect human and commodity that will come and leave from Samosir to the lands of Sumatera or otherwise. Thus, this region needs to be redevelopment using every potential resource to be a commercial resource. In the end, Tomok Village Dockyard should be attractive and give a great experience of Batak Toba culture.

\section{Literature Review}

\subsection{Dockyard}

The dock is a building on the edge of the sea (river, lake) that serves to serve the ship, in loading/unloading of goods and raising/lowering passengers [1]. The jetty can be divided into two types: wharf and jetty or pier or bridge. Wharf is a parallel dock with a beach and usually coincides with the coastline. Jetty or pier is a jetty that juts into the sea [7]. The function of the dock in the tourism area is to increase the passengers of both tourists and the public, transporting and unloading cargo related to the goods needs of tourists and the community, connecting transport from and to the land or vice versa to facilitate the activities of tourists and the public. Docked, tethered and unleashes ships carrying tourists and the public, and is a facility related to land traffic. The benefits of the dock in the area of tourism are to provide facilities and infrastructure for tourism and then increase tourist arrivals to the tourism area and increase economic activity in the Tourism area.

\subsection{Neo-Vernacular}

Neo-Vernacular is a form and style born from the branches of modern architecture (emerged in the late XIX and XX centuries). Vernacular architecture is the development of a folk architecture that has ecological, natural and architectural value because it refers to the natural conditions, environment, and culture of the community [5].

In Neo-Vernacular architecture, not only apply the physical elements applied in modern form but also non-physical elements such as culture, mindset, belief, layout, religion, and others. The Neo-Vernacular architecture is intended to keep preserving local elements with modernization layers. In Neo-Vernacular architecture found many forms that are very modern, but in its application still use the old, concept of the local area that is packed in a modern form. This Neo- 
Vernacular architecture shows a modern form but still has an image of the local area although the material used in modern materials such as glass and metal. In neo-vernacular architecture, the idea of forms is taken from the original vernacular developed in the form. The characteristics of Neo-Vernacular Architecture as follows: (1) Always use the roof (2) Bricks (in this case is elements of local construction) (3) Restoring traditional forms (4) Unity between open interiors through modern elements with open space outside buildings (5) Strong and contrasting colors [3].

Innovative cultivation has contributed much to the movement of architectural modernization in Indonesia towards the goal of modern National identity. The Vernacular Architectural Style contributes to the development of the modern Post architecture in the form of NeoVernacular architecture. An Architectural display that does not fully apply the rules of vernacular rules, but tries to display visual expressions such as Vernacular buildings. "Noe-Vernacular architecture is a strand of post-modernism marked by a deliberate return to traditional, especially local models. Bringing back the detailing, but seldom the construction method " [6]. The appearance of the "Neo-Vernacular" architecture varies greatly, for example, Darbourne \& Darke in England, reproducing bricks as a traditional material used to build houses in Lillington, providing a different community atmosphere. In other countries, the use of "neo vernacular" such as Sukarno-Hatta International Airport, Indonesia.

Huta Tomok Tourism Pier which will be designed with ethnicity / thick feel with cultural nuances that are visually packed modern but still able to preserve cultural image in accordance with the culture, which is intended to give a different visual impression of vernacular formation, so neo vernacular very appropriately applied in design approach Huta Tomok Tourism Pier is physically applied vernacular building principles that are packaged in modern so different from the visual vernacular, to support the creation of cultural nuance is then applied non-physical elements such as culture, mindset, beliefs, layout, religion, and others so nuances custom can be felt visitors Huta Tomok Tourism Pier.

\section{Methodology}

Conditions from a location of design is a function of crossing docks from Ajibata to Tomok and otherwise. The location includes sales retail dan empty sites. Site width is $12.459 \mathrm{~m} 2$. There are several potentials that strongly support this site to serve as the site "Huta Tomok Tourism Pier." Some of these factors include achievement or good accessibility, both from the lake and the land. Due to being on the national road, Jln Pulau Samosir (Figure 1). 


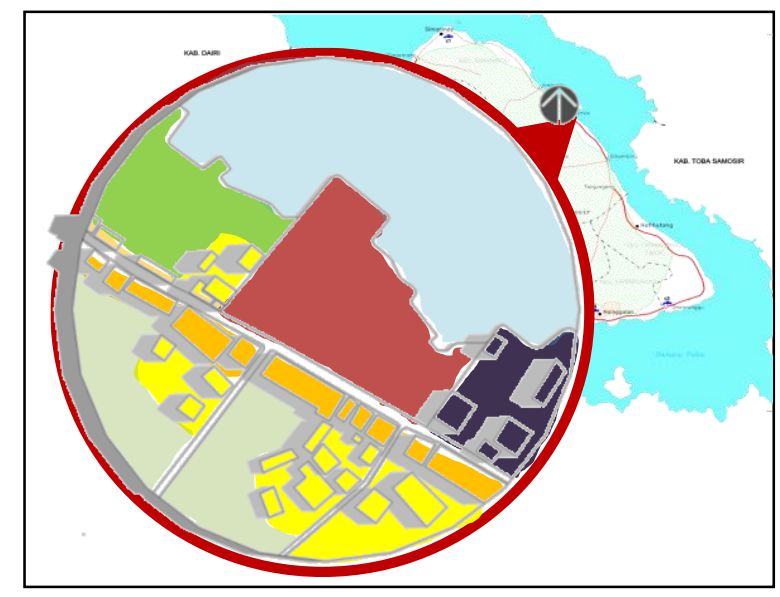

Figure 1. Environment Sites

(Source: http//www.goegle.earth.com)

To obtain concrete data in field research, the research design in this seminar, the researcher uses qualitative descriptive research. The notion of a qualitative method as proposed by Kirk and Miller concluded by Lexy J. Moleong is a certain tradition in social science fundamentally dependent on human observations in its region, and relates to such persons, its discussion, and terminology [4]. Qualitative research is research conveyed on people or object to receive descriptive data. Researcher's planning to apply research methods such as (1) Documentation (2) Observation (3) Data Analysis (4) Analytical Methods (5) Layer Analysis (6) Building Analysis (7) Physical Elements Analysis (8) Utility Analysis.

\section{Result and Discussion}

The background of water transportation infrastructure in Tomok Village with a small site and lack of conditioning, this sites needs to remodel by changing crossing sites that used to be crossing sites only with no attractions change to be crossing facility that has another function expectations by users. Building shape mass follows a topographical pattern and existing sites conditions (Figure 2).

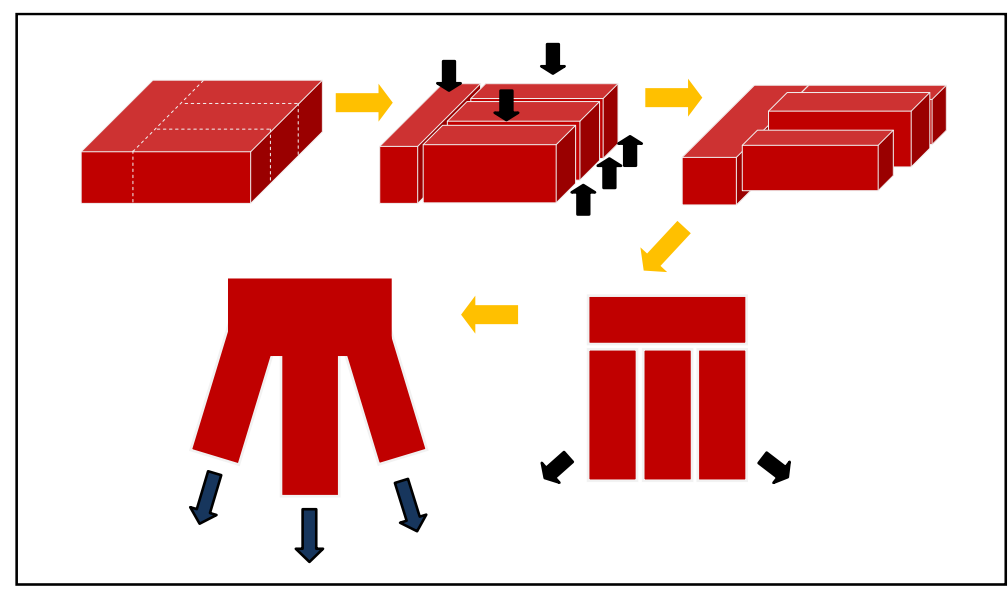

Figure 2. Shape-Mass 
(Source: Author, 2018)

Dividing the mass to three parts to separate function and giving the solar enlightenment to the building, then the directions of building mass pointing to all points if the insides give a welcoming experience from all points either. Designers hope the design as the beginning of tourism in Toba Lake and Samosir Island. Neo-vernacular architectural design approach used to rise and introduce it to the worldwide about the Batak Toba culture (Figure 3).

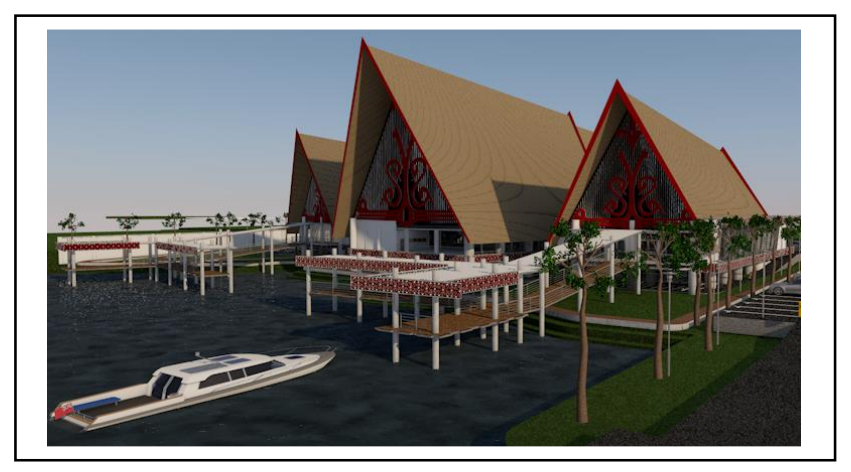

Figure 3. Building Visual Mass Shape

Divisions of functions are needed to manage to build mass in designing process. This activity system will divide activities according to zones used to do any activities. These zones divide into a general zone, passengers only zones, manager's only zones, services zones, and parking zones (Table 1).

Table 1: Zone Division

\begin{tabular}{|c|c|c|c|c|}
\hline General Zones & $\begin{array}{l}\text { Passengers } \\
\text { Only Zones }\end{array}$ & $\begin{array}{l}\text { Manager's } \\
\text { Only Zones }\end{array}$ & $\begin{array}{c}\text { Services } \\
\text { Zones }\end{array}$ & $\begin{array}{l}\text { Parking } \\
\text { Zones }\end{array}$ \\
\hline $\begin{array}{l}\text { - Arrival } \\
\text { Corridor } \\
\text { - Departure } \\
\text { Corridor } \\
\text { - Departure Hall } \\
\text { - General Hall } \\
\text { - Information } \\
\text { Center dan } \\
\text { Gallery } \\
\text { - Support } \\
\text { Facilities }\end{array}$ & $\begin{array}{l}\text { - Arrival/ } \\
\text { Departure } \\
\text { Lobby } \\
\text { - Arrival/ } \\
\text { Departure } \\
\text { Corridor } \\
\text { - Waiting } \\
\text { Room } \\
\text { - Loading } \\
\text { dock }\end{array}$ & $\begin{array}{l}\text { - Manager's } \\
\text { Room } \\
\text { - Office Room } \\
\text { - Secretary } \\
\text { Room } \\
\text { - Administratio } \\
\text { n Room } \\
\text { - Meeting } \\
\text { Room }\end{array}$ & $\begin{array}{l}\text { - Pumping } \\
\text { Room } \\
\text { - Panel Room } \\
\text { - Generator } \\
\text { Room } \\
\text { - Warehouse } \\
\text { - Toilet }\end{array}$ & $\begin{array}{l}\text { - Visitors } \\
\text { Parking } \\
\text { - Departure } \\
\text { Parking } \\
\text { - Staff Parking }\end{array}$ \\
\hline
\end{tabular}

Outer Room Concept: Vehicle circulation divide into two parts such as vehicle circulation for passengers and pedestrians made circling the sites so visitors can access the whole sites (Figure 4). 


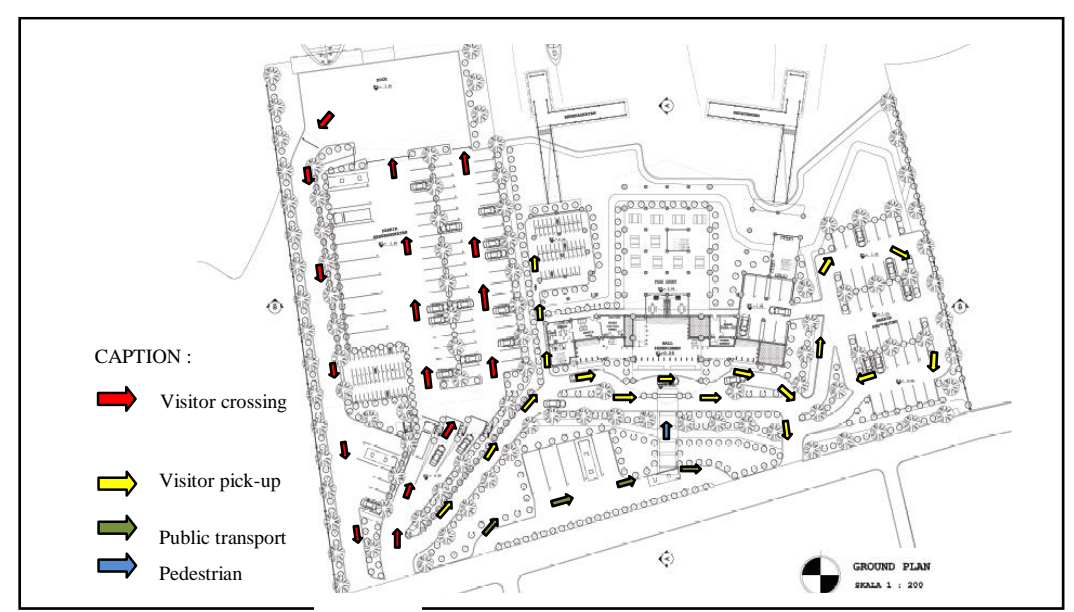

Figure 4. Outer Room Concept

Inside Room Concept: Spatial in the site will be tailored to the needs where all indoor space activities are in one lifetime of the building with the circulation of interconnected. Applied to concepts on buildings, visitors and passengers will be directed to main hall or arrival/departure hall, on the same elevation, there are food court and services, the parts of this building used as parking sites too. Beneficial concepts of a lower room based on contour sites conditions, with decreasing contour to the lake uses as rooms that can be used better, at the bottom, it is focused on the public space (Figure 5).

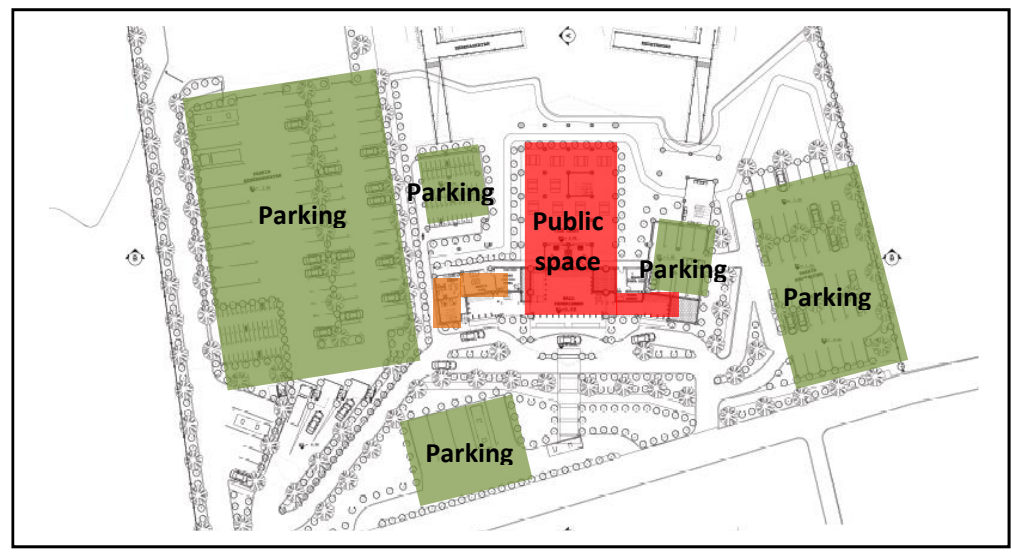

Figure 5. Ground Plan Activity Zones Concept

On the higher level, this building connected with circulations with Arrival/Departure hall centered on the main hall. The main hall is a gathering point for all activities and circled with several functions (Figure 6). By using a typical roof of a hobo house with a 60-degree slope, then there is space leftover that can be used. In this case, space is used as a space for the restaurant (Figure 6). 


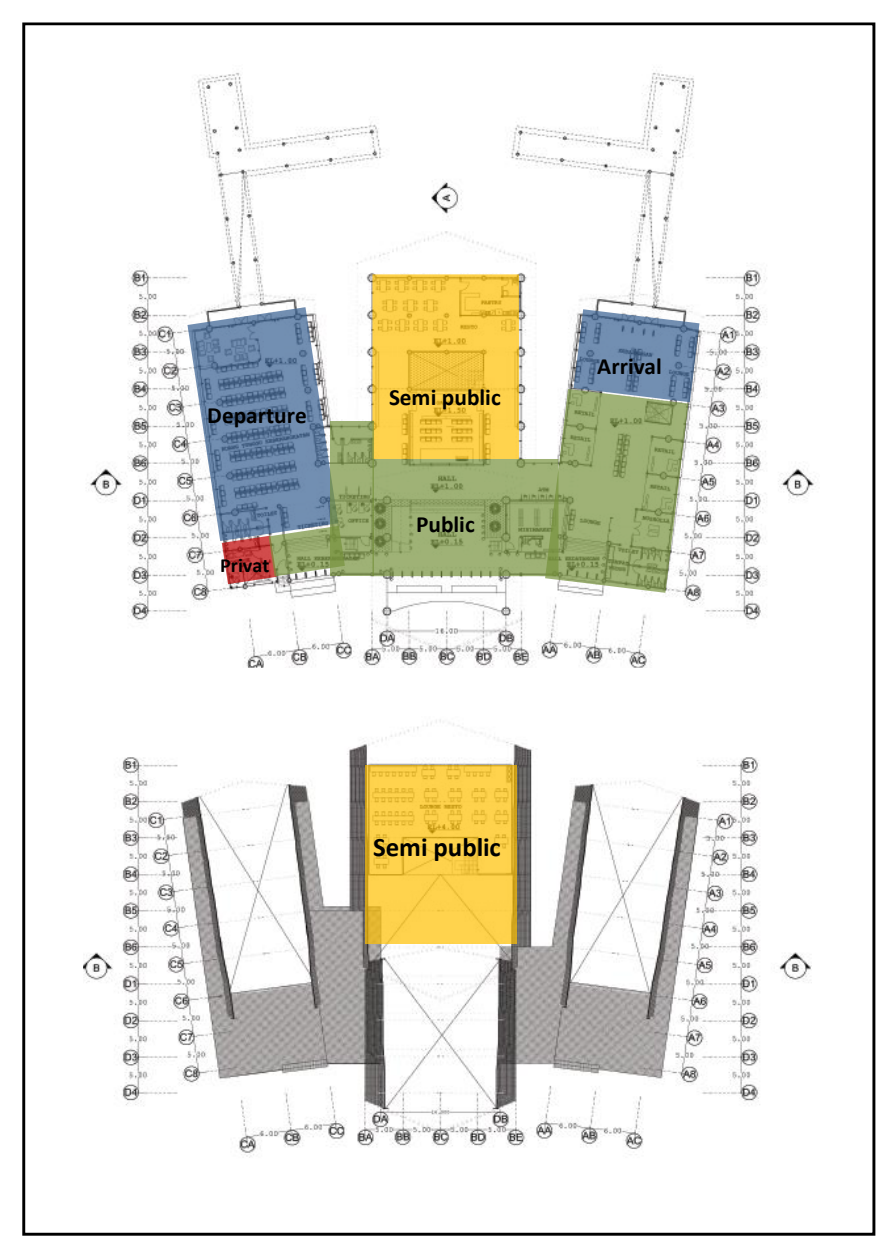

Figure 6. Activity Zones Concept

The mass and building of the building took from the theme of Neo-Vernacular Traditional House of Batak Toba. Where the traditional house of Batak Toba separates the function according to the user who is divided into three namely the cattle - humans - the god of trust, then on the concept of Huta Tomok Tourism Pier period will use the principle of segregation of functions based on the user.

In this design, the principle of division of mass by function, where the period is divided into three parts, namely the function of departure, arrival function and the function of public facilities. These three parts have their building masses with the same roof formation but have different magnitudes. Then these three masses are connected by the fourth mass, this mass consists of one main roof with two left and right wings using a roof with no concrete (Figure 7). 


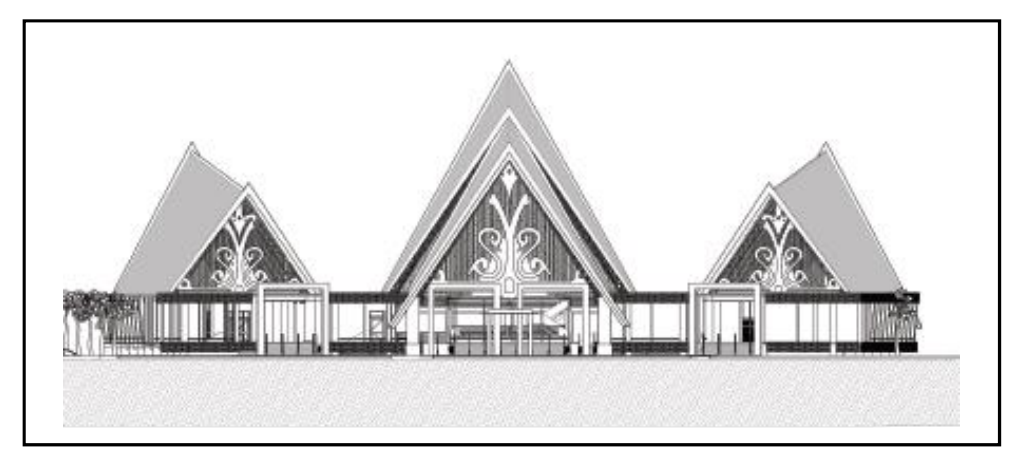

Figure 7. Mass and building

In addition to the separation of mass by function, the formation of the entrance of the custom house of Batak will be a detail that will be used in buildings where the entrance house of Batak Toba custom has a philosophy of respecting the homeowner by way of entering the house a little lowered to deliver beam across the head so as not to collide. To apply the philosophy of respecting these residents will be used on the corridors and access to this building. The building will feature typical Toba Batak ornaments. The decoration used in traditional Batak Toba architecture is the art of carving and painting. This shows that beauty is one of the very closely related things in human life. In addition to the beauty, the decoration that existed in the traditional Batak Toba house also has a very important value in determining the identity of the inhabitants of the house. Therefore, in addition to the form of the house, ornaments are also a pride and appreciation given to show the inhabitants of the house. With the decoration of the traditional Batak Toba house, it can be used as a specific value owned by a house as a personal building, not just a traditional building. Then the use of Toba Batak ornament will be adjusted to the function of this building (Figure 8).

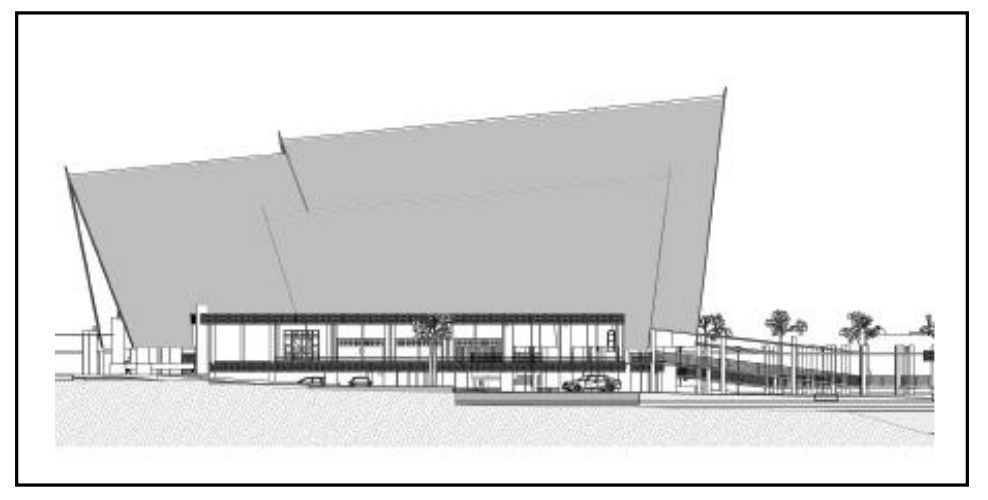

Figure 8. Mass and building

Building structures use to post and beam systems as floor structures. The roof structure uses a truss structure that also serves as a wall covering. In general, the column grids on the building are linear. The foundation structure uses a reinforced concrete pile foundation with different size considering the number of different roofs (Figure 9). 


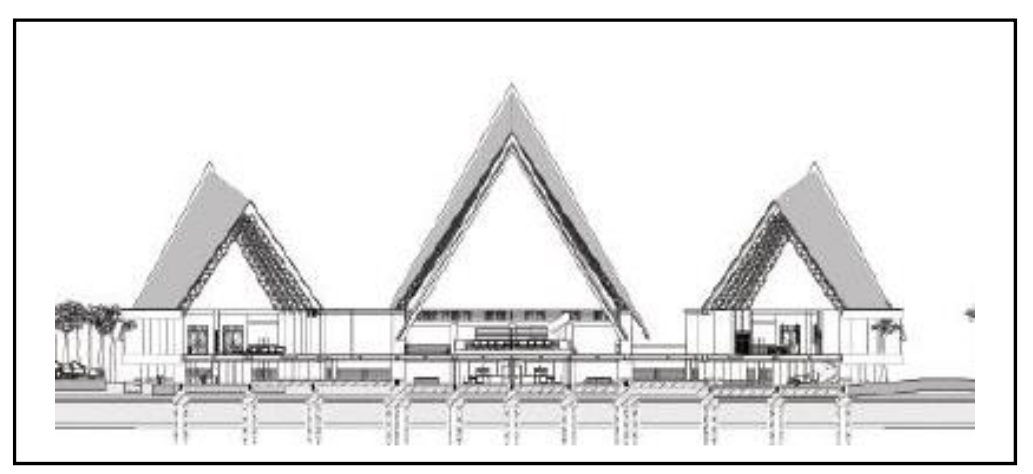

Figure 9. Section building

\section{Conclusion}

Tomok Village Dockyard development in Samosir designed with Neo Vernacular concept with site 1.5 Ha. The shape of the building based on essentials from "Rumah Adat Batak Toba" building and combining modern elements to receive improvement value. For the organization of form and placement of building footprint and orientation obtained from the analysis of the site which is contoured land but has added value to the right edge of Lake Toba which ultimately adds the aesthetic value of the building. This building is function as the center of crossing from Samosir Island or otherwise to provide the needs of locals in transportations that keep increasing because of Samosir Island tourism improvements.

\section{Acknowledgment}

This journal is made as a requirement to get a degree from the Architecture Department Faculty of Engineering, Universitas Sumatera Utara.

\section{REFERENCES}

[1] Asiyanto. Metode Konstruksi Bangunan Pelabuhan. Jakarta: Penerbit Universitas Indonesia. 2008.

[2] N. Ginting, N. V. Rahman, and A. D. Nasution. Increasing Tourism in Karo District, Indonesia Based on Place Identity. Environment-Behaviour Proceedings Journal, 2(5), 177-184. 2017.

[3] C. Jencks. A Post-Modern Architecture. Rhétorique et image: textes en hommage à A. Kibédi Varga, (98), 35. 1995.

[4] L. Moleong. The notion of qualitative methods such as those proposed. 2003.

[5] V. Papanek. The Lesson of Vernacular Architecture, in Green Imperative. The Thames in Hudson, New York. 1995.

[6] L. Peel. Architecture, Chartwell Books, New Jersey,. pp.125. 1989.

[7] B. Triatmodjo. Perencanaan Pelabuhan. Yogyakarta: Beta Offset. 2009. 